\title{
Stemming the Brain Drain from the Caribbean Postgraduate Medical Education at The University of the West Indies Reform and Expansion of the Faculty of Medicine M Ragbeer
}

By the mid-1960s, a steady drain of Caribbean doctors to Canada, the United States of America (USA) and the United Kingdom was subsidizing these already well-endowed health systems, and depriving the struggling Caribbean economies of millions of rare dollars annually. This uncompensated loss denied the region of half or more of the annual output of doctors from The University of the West Indies (UWI). This book deals with the challenges that poor nations face when they seek to develop educational programmes of high standard, free of external vested interests and control. It describes the actions taken at that crucial time in UWI history, soon after its independence from London University, when it was expanding, facing financial and social difficulties, with internal want and unrest, and external pressures threatening its integrity. This was a time of global conflict, the Cold War and student protests, spreading in and from the USA.

Immersed in this problem from the mid-1960s and the need for other reforms, the author became the first full-time Dean of the Medical Faculty at Mona, Jamaica, in 1971, and worked with medical colleagues and a few from other faculties and with external agencies (whose names are given in the book) to combat the forces threatening UWI's existence as a regional body and threatening to destroy its potential to unite the 14 units of the Commonwealth Caribbean that funded it, and gave its scholars a place and a voice. Given the bare minimum in resources, he and others initiated a series of reforms and innovations in medical education, programmes and policies to produce a range of specialists, family doctors and other manpower, and start a novel division of Community Medicine tailored to Caribbean needs.
By offering these incentives to graduates, they hoped to stem the 'brain drain'. Jamaica's Prime Minister at the time, Michael Manley, urged him to turn 'fantasy to reality', and other Caribbean leaders agreed. The plan was bold and costly, but the Dean's office persisted, over the skepticism, gratuitous criticisms and ridicule of some influential foreign observers, and later 'threats' by entrepreneurs in the USA, who were luring each island for use as bases for American medical education for profit. Ten years later, one skeptical journalist who had labelled the author a dreamer summarized his work as 'high quality on a low budget'.

Today, the UWI Faculty of Medical Sciences thrives on three campuses and produces enough doctors, generalists and specialists for Caribbean needs and some even for export. The output continues, through Master's and Doctorate programmes: from aides and assistants to nurse practitioners, administrators and educators, family and specialist doctors, dentists, veterinarians, and a range of technicians and basic scientists, who now provide medical services for the Commonwealth Caribbean. The Community Medicine programme as proposed by UWI was not pursued, but the concept (described in the book) remains valid and survives as a document that, although eventually shelved, had received preliminary approval by the Ontario Ministry of Health in Canada. The book includes commentary, tables of data, photographs, and an appendix with copies of original documents and published papers.

Professor M Ragbeer, Honourary Consultant, Hamilton Health Sciences Corporation, Hamilton, Canada. Email: mohan.ragbeer@gmail.com 